\title{
Control of PMSG based variable speed wind energy conversion system connected to the grid with PI and ADRC approach
}

\author{
Youssef Barradi ${ }^{1}$, Khalida $\mathrm{Zazi}^{2}$, Malika Zazi ${ }^{3}$, Naoufel Khaldi ${ }^{4}$ \\ 1,2,3 Departement Electrical Engineering Department in The Higher School of Technical Education (ENSET), Mohammed \\ V University, Morocco \\ ${ }^{4}$ Department of Electrical Engineering, Mohammadia School of Engineering, Mohamed V University, Morocco
}

\begin{tabular}{l}
\hline \hline Article Info \\
\hline Article history: \\
Received Aug 24, 2019 \\
Revised Oct 23, 2019 \\
Accepted Dec 15, 2019 \\
\end{tabular}

Keywords:

ADRC controller

Linear extended state observer MPPT

PI controller

PMSG

Wind turbine

\begin{abstract}
This paper presents the modeling and simulation of wind energy Conversion System using the Permanent Magnet Synchronous Generator (PMSG). The objectives are: to extract the maximum power of the wind speed by controlling the electromagnetic torque of the PMSG, to maintain constant the DC-link voltage despite the wind speed variations and to attain the unity power factor. In order to ensure a regulation with high performance and a good robustness against the internal and the external disturbances, a new control strategy called the Active Disturbance Rejection Control (ADRC) is used. Therefore, the Analysis and simulation of the ADRC and PI controllers are developed with MATLAB/Simulink software. The performance of these controllers is compared in term of references tracking, robustness and grid faults.
\end{abstract}

This is an open access article under the CC BY-SA license.

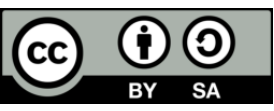

\section{Corresponding Author:}

Youssef Barradi, Departement Electrical Engineering, Department in The Higher School of Technical Education (ENSET), Mohammed V University, BP 6207 Rabat, Morocco.

Email: barradiyoussef.electrique@gmail.com

\section{INTRODUCTION}

In the recent years, wind energy became a famous clean energy source. The wind energy source systems are quickly growing thanks to the innovations and the researches in wind energy technology for electrical power production. Originally, a wind power source was used in standalone applications, however, wind systems connected directly to the grid [1]. Three types of generators are mainly usable in the wind energy conversion system: the squirrel cage induction generator (SCIG), doubly fed induction generator (DFIG) and Permanent Magnet Synchronous Generator (PMSG).For this work, the PMSG is used since it has small size, provides a self excitation and a high power density. In addition, the generator has the capacity to control reactive power, working also without the gearbox due to the higher number of poles for low speed operation [2, 3]. A configuration of a wind power system based on the PMSG is illustrated in Figure 1. The synchronous generator is connected to the grid through a back-to-back converter composed of the generator side converter and the grid-side converter [4].

The last years, many researches have appeared documenting the control of nonlinear systems related to wind energy. In the literature, proportional integral (PI) controllers based on field oriented control (FOC) is made up, this conventional technique presents some shortcomings, such as a low accuracy especially with the disturbance and nonlinearities according to dynamic characteristics of systems [5]. In order to overcome the disadvantages of the conventional PI controller which suffers from many limitations, a new control strategy called Linear Active Disruption Rejection Control (ADRC) founded by Han in 1995 is adopted to 
remove disturbances affecting the facility [6,7]. This paper introduced an advanced method as the linear active disturbance rejection control (ADRC) based on vector control, in order to achieve a maximum power extraction, to maintain the DC bus at desired voltage value through the DC-link circuit, and to meet power stable of the wind energy conversion system [8].

In detail, the suggested design techniques propose a comparison between PI and ADRC technique which have been explored and used recently as a new technology for estimating and compensating uncertainties and disturbances, is based on Extended state Observer (ESO) which is the main part of the command. An evaluation is ensured to control the grid and generator side converter in order to regulate the electromagnetic torque and the stator current of the PMSG. Simulation is made under MATLAB/Simulink environment with a comparison between both commands. Results provided show clearly the feasibility and the effectiveness of the proposed two techniques. They present also a good characteristic, excellent output from the ADRC control comparing with PI command especially in terms of robustness and reference tracking. The sequential work flow of this paper is as follows: In section 2, complete architecture of the variable speed wind turbine conversion chain based on the PMSG has been described and the model has been determined. Section 3 covers both PI and ADRC design, followed by a control of grid side converter, bus voltage and generator side converter of the PMSG to maximize the production of the wind energy using respectively both controllers in section 4 and 5. Simulation results and discussion are made in section 6 . Lastly, in section 7, a conclusion has been added to finalize the work.

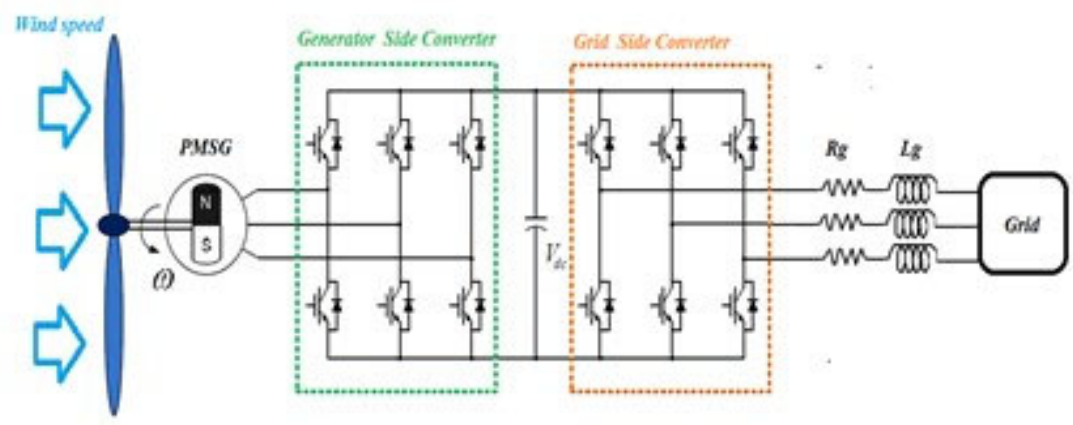

Figure 1. Architecture of the variable speed wind turbine conversion chain based on the PMSG

\section{MODELING OF THE WIND ENERGY CONVERSION SYSTEM BASED ON THE PMSG}

2.1. Wind turbine

The turbine transforms the wind energy into a mechanical energy available on a wind turbine rotor $[9,10]$. This power is expressed by:

$$
P_{t}=\frac{1}{2} C_{p}(\lambda, \beta) \rho \pi R^{2} V^{3}
$$

Where $\rho$ is the air density, $\mathrm{R}$ is the turbine radios and $\mathrm{V}$ is the wind velocity. The power coefficient $\mathrm{Cp}$ is given by the following expression $[11,12]$ :

$$
C_{p}(\lambda, \beta)=C_{1}\left(\frac{C_{2}}{\lambda_{i}}-C_{3} \beta-C_{4}\right) e^{\left(-\frac{C_{5}}{\lambda_{i}}\right)}+C_{6} \lambda
$$

where:

$$
\begin{aligned}
& \left\{\begin{array}{c}
\lambda=\frac{\Omega_{\mathrm{t}} \mathrm{R}}{\mathrm{V}} \\
\frac{1}{\lambda_{\mathrm{i}}}=\frac{1}{\lambda+0.08 \beta}-\frac{0.035}{1+\beta^{3}}
\end{array}\right. \\
& \mathrm{C}_{1}=0.5176, \mathrm{C}_{2}=116, \mathrm{C}_{3}=0.4, \mathrm{C}_{4}=5, \mathrm{C}_{5}=21, \mathrm{C}_{6}=0.0068
\end{aligned}
$$


The maximum value of power coefficient $\mathrm{Cp}$ is $\mathrm{C}_{\mathrm{pmax}}=0.48$, is achieved for pitch angle of rotor blades $\beta$ is set to zero and $\lambda_{\text {opt }}=8.1$, this point corresponds at the maximum power point tracking (MPPT). This model is translated by the following equation [21]:

$$
\mathrm{T}_{\mathrm{t}}=\mathrm{T}_{\mathrm{g}}+\mathrm{f}_{\mathrm{v}} \Omega_{\mathrm{g}}+\mathrm{J} \frac{\mathrm{d} \Omega_{\mathrm{g}}}{\mathrm{dt}}
$$

Where Tg and Tem are respectively the mechanical and the electromagnetic torque of PMSG, $\mathrm{J}$ is the total moment of inertia and $\mathrm{fv}$ is the friction coefficient of the turbine. The electromagnetic torque reference is determined by the following equation:

$$
\mathrm{T}_{\mathrm{em}-\mathrm{ref}}=\frac{1}{2 \lambda_{\mathrm{opt}}^{3}} \mathrm{C}_{\mathrm{pmax}} \rho \pi \mathrm{R}^{5} \widehat{\Omega}^{2}
$$

The Figure 2 represents the block diagram of the turbine model with MPPT strategy:

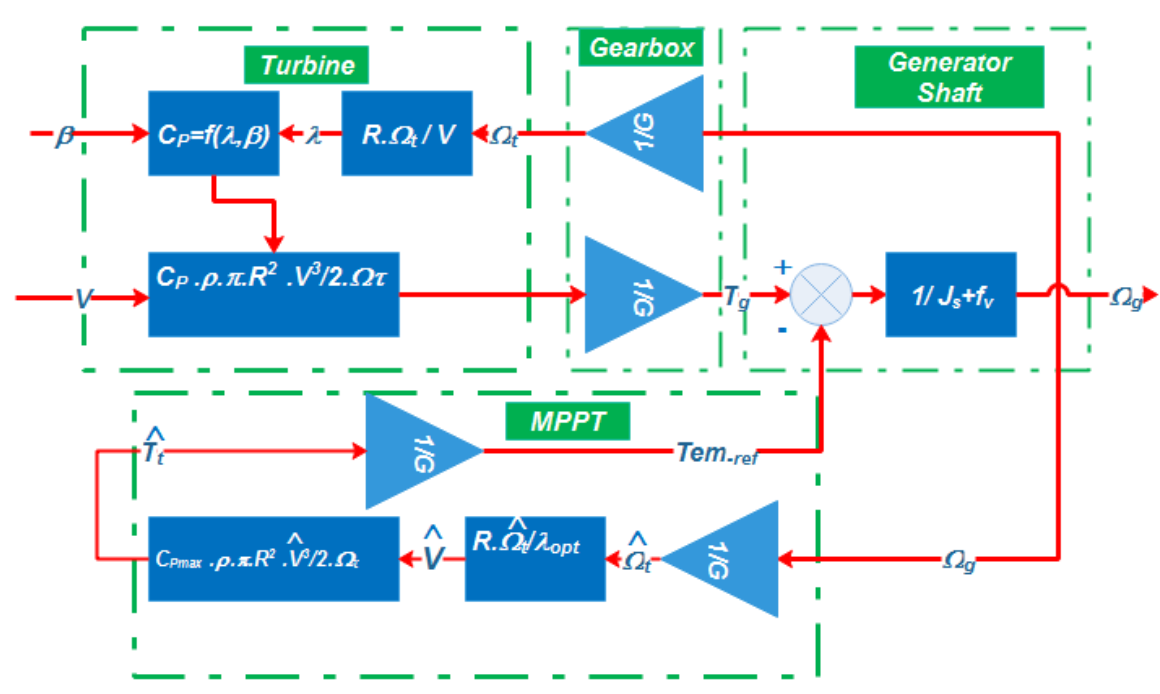

Figure 2. Model of the turbine with MPPT strategy

\subsection{Model of converters}

The generator side converter and grid side converter are controlled by the PWM control. These converters are represented by simple line voltages and the control signals $\mathrm{Si}$ (6) [8].

$$
\left\{\begin{array}{l}
\mathrm{v}_{\mathrm{a}}=\frac{2 \mathrm{~S}_{1}-\left(\mathrm{S}_{2}+\mathrm{S}_{3}\right)}{3} \mathrm{U}_{\mathrm{dc}} \\
\mathrm{v}_{\mathrm{b}}=\frac{2 \mathrm{~S}_{2}-\left(\mathrm{S}_{1}+\mathrm{S}_{3}\right)}{3} \mathrm{U}_{\mathrm{dc}} \\
\mathrm{v}_{\mathrm{c}}=\frac{2 \mathrm{~S}_{3}-\left(\mathrm{S}_{2}+\mathrm{S}_{1}\right)}{3} \mathrm{U}_{\mathrm{dc}}
\end{array}\right.
$$

\subsection{Modeling of the PMSG}

The electrical voltages of the PMSG are given by the following equations:

$$
\left\{\begin{array}{l}
\mathrm{v}_{\mathrm{ds}}=\mathrm{R}_{\mathrm{s}} \mathrm{i}_{\mathrm{ds}}+\mathrm{L}_{\mathrm{d}} \frac{\mathrm{di}_{\mathrm{ds}}}{\mathrm{dt}}+\mathrm{e}_{\mathrm{ds}} \\
\mathrm{v}_{\mathrm{qs}}=\mathrm{R}_{\mathrm{s}} \mathrm{i}_{\mathrm{qs}}+\mathrm{L}_{\mathrm{q}} \frac{\mathrm{di}_{\mathrm{qs}}}{\mathrm{dt}}+\mathrm{e}_{\mathrm{qs}}
\end{array}\right.
$$

Where the direct and the quadrature e.m.f components are expressed as follow: 


$$
\left\{\begin{array}{c}
\mathrm{e}_{\mathrm{ds}}=-\omega_{\mathrm{s}} \mathrm{L}_{\mathrm{q}} \mathrm{i}_{\mathrm{qs}} \\
\mathrm{e}_{\mathrm{qs}}=\omega_{\mathrm{s}} \mathrm{L}_{\mathrm{d}} \mathrm{i}_{\mathrm{ds}}+\omega_{\mathrm{s}} \phi_{\mathrm{f}}
\end{array}\right.
$$

Where:

$\mathrm{L}_{\mathrm{d}}, \mathrm{L}_{\mathrm{q}}$ are $\mathrm{d}$ and $\mathrm{q}$ axis inductances $(\mathrm{H})$;

$\mathrm{R}_{s}$ is the stator resistance $(\Omega)$;

$\mathrm{i}_{\mathrm{ds}}, \mathrm{i}_{\mathrm{qs}}$ are the $\mathrm{d}$ and $\mathrm{q}$ axis machine current $(\mathrm{A})$;

$\phi_{\mathrm{f}}$ is the flux linkage established by the permanent magnets in the stator windings $(\mathrm{Wb})$;

$\omega_{\mathrm{s}}$ is the angular frequency of the stator voltage $(\mathrm{rad} / \mathrm{s})$;

The expression of the electromagnetic torque is also expressed as a function of currents "(9)":

$\mathrm{T}_{\mathrm{em}}=\frac{3}{2} \mathrm{p} \phi_{\mathrm{f}} \mathrm{i}_{\mathrm{qs}}+\frac{3}{2} \mathrm{p}\left(\mathrm{L}_{\mathrm{d}}-\mathrm{L}_{\mathrm{q}}\right) \mathrm{i}_{\mathrm{ds}} \mathrm{i}_{\mathrm{qs}}$

p: Pairs of poles

These equations have been grouped to form a simplified model of PMSG as depicted in Figure 3.

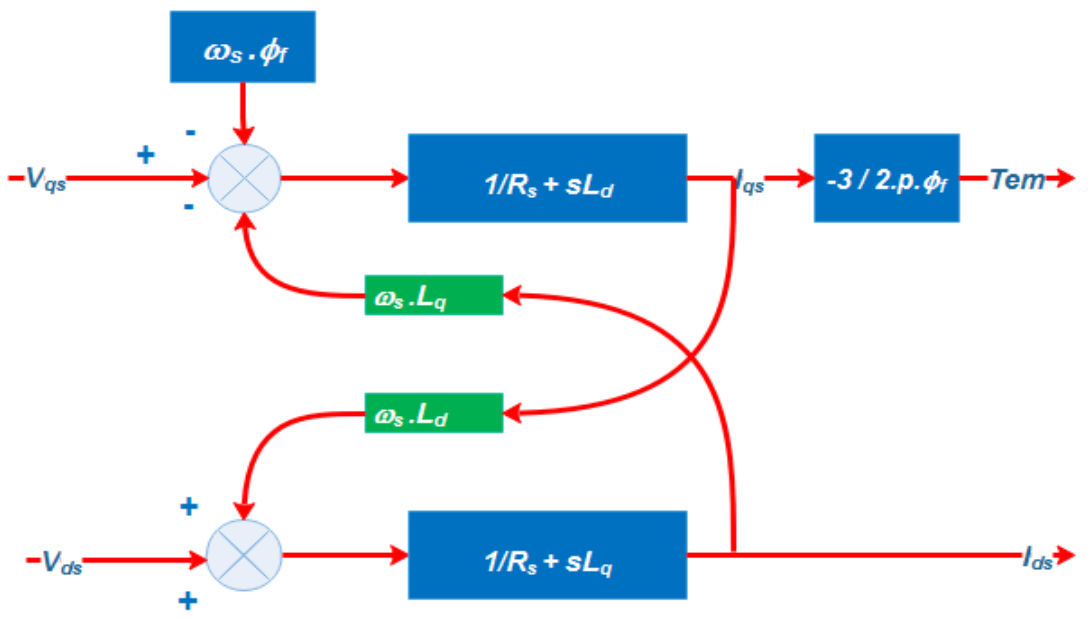

Figure 3. Simplified Theoretical Model of PMSG

\subsection{Modeling of RL grid filter and DC link}

The electrical voltages of the grid-side are given in the $(d, q)$ reference frame by the following equations:

$$
\left\{\begin{array}{l}
\mathrm{v}_{\mathrm{md}}=\mathrm{R}_{\mathrm{g}} \mathrm{i}_{\mathrm{dg}}+\mathrm{L}_{\mathrm{g}} \frac{\mathrm{di} \mathrm{dg}_{\mathrm{dg}}}{\mathrm{dt}}+\mathrm{e}_{\mathrm{dg}} \\
\mathrm{v}_{\mathrm{mq}}=\mathrm{R}_{\mathrm{g}} \mathrm{i}_{\mathrm{qg}}+\mathrm{L}_{\mathrm{g}} \frac{\mathrm{di} \mathrm{i}_{\mathrm{gg}}}{\mathrm{dt}}+\mathrm{e}_{\mathrm{qg}}
\end{array}\right.
$$

Where the direct and the quadrature e.m.f components are expressed as follow:

$$
\left\{\begin{array}{c}
e_{d g}=-\omega_{s} L_{g} i_{q g}+i_{d g} \\
e_{\text {qg }}=\omega_{s} L_{g} i_{d g}
\end{array}\right.
$$

The active and reactive power supplied to the network can be expressed as :

$$
\left\{\begin{array}{l}
P_{g}=v_{d g} \cdot i_{d g}+v_{q g} \cdot i_{q g} \\
Q_{g}=v_{q g} \cdot i_{q g}-v_{d g} \cdot i_{q g}
\end{array}\right.
$$

The grid voltagevector is oriented on d-axis, then: 


$$
\left\{\begin{array}{c}
\mathrm{v}_{\mathrm{dg}}=\mathrm{V}_{\mathrm{g}} \\
\mathrm{v}_{\mathrm{qg}}=0
\end{array}\right.
$$

Thus:

$$
\left\{\begin{array}{l}
P_{g}=v_{d g} \cdot i_{d g} \\
Q_{g}=-v_{d g} \cdot i_{q g}
\end{array}\right.
$$

The dc-link capacitor is interface between generator side converter and grid side converter; By neglecting the converters losses, the state equation of the dc-link voltage are expressed as follow:

$$
\mathrm{V}_{\mathrm{dc}}=\frac{1}{\mathrm{C}} \int \mathrm{i}_{\mathrm{c}} \mathrm{dt}=\frac{1}{\mathrm{C}} \int\left(\mathrm{i}_{1}-\mathrm{i}_{2}\right) \mathrm{dt}
$$

where

C: the DC link Capacitor.

\section{SYNTHESIS OF PI AND ADRC CONTROLLERS}

\subsection{PI controller}

The proportional-Integral controller is a combination of both actions proportional and integral in order to cancel the static error. The structure of a parallel PI controller system is represented in Figure 4 $[10,11,16]$. The derivative action of PID controller is excluded because it is characterized by amplifying the effect of system noise.

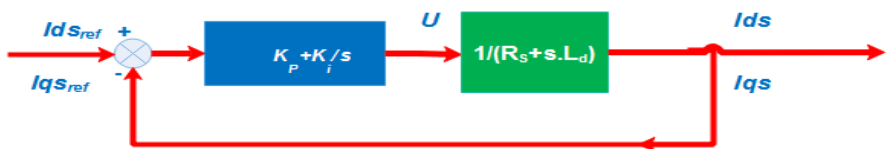

Figure 4. Structure of PI controller system for the PMSG

\subsection{Linear ADRC controller}

The mathematic expression of the first order for a time-varying dynamic system with single input $u$ and single-output $y$ is given as follow [13-16].

$$
\frac{d y}{d t}=f(y, d, t)+b_{0} u
$$

where:

$\mathrm{f}(\mathrm{y}, \mathrm{d}, \mathrm{t})$ : the effect of internal and external disturbances, b0 : Represents parameter gain to estimate .

$\mathrm{d}:$ The external disturbance.

The mathematical system as follow describes the process [19-21]:

$$
\begin{aligned}
& \left\{\begin{array}{c}
\dot{\mathrm{x}}_{1}=\mathrm{x}_{2}+\mathrm{b}_{0} \mathrm{u} \\
\mathrm{x}_{2}=\mathrm{f} \\
\mathrm{y}=\mathrm{x}_{1}
\end{array}\right. \\
& \left\{\begin{array}{c}
\hat{\mathrm{x}}_{1}=\hat{\mathrm{x}}_{2}+\beta_{1}\left(\mathrm{y}-\hat{\mathrm{x}}_{1}\right)+\mathrm{b}_{0} \mathrm{u} \\
\hat{\mathrm{x}}_{2}=\beta_{2}\left(\mathrm{y}-\hat{\mathrm{x}}_{1}\right)
\end{array}\right.
\end{aligned}
$$

Where the vector of the observer gain is expressed by:

$$
\left[\begin{array}{l}
\beta_{1} \\
\beta_{2}
\end{array}\right]=\left[\begin{array}{c}
-2 \mathrm{~S}_{\mathrm{ESO}} \\
\mathrm{S}_{\mathrm{ESO}}^{2}
\end{array}\right]
$$


The pole of the observer SESO is determined by the technique of placement of the poles. Therefore, the control plant can be ensured by a simple proportional $K_{p}(18)$. The input signal reference denoted $r$ $[20,21]$.

$$
\mathrm{u}_{0}=\mathrm{K}_{\mathrm{p}}(\mathrm{r}-\hat{\mathrm{y}})=\mathrm{K}_{\mathrm{p}}\left(\mathrm{r}-\hat{\mathrm{x}}_{1}\right)
$$

where:

$\mathrm{Kp}=\mathrm{SCL}$.

SCL is the pole of desired closed loop.

$\mathrm{SESO}=3 \sim 7 \mathrm{SCL}$

The only setting parameter is SCL.

Figure 5 represent the Structure of ADRC controller and the ESO

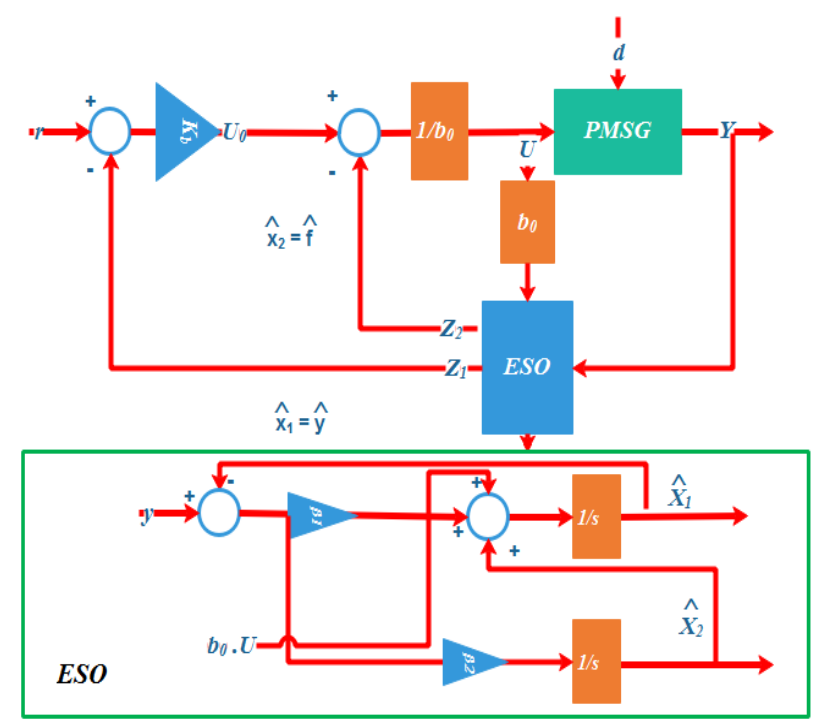

Figure 5. Structure of ADRC controller and the ESO

\section{CONTROL OF THE WIND SYSTEM BY PI CONTROLLER}

4.1. Control of the generator side converter

The stator current is aligned on the $q$-axis (isd $=0$ ). Consequently, the electromagnetic torque is controlled by the q-axis current isq: The expression of the electromagnetic torque (9) become:

$\mathrm{T}_{\mathrm{em}}=\frac{3}{2} \mathrm{p} \phi_{\mathrm{f}} \mathrm{i}_{\mathrm{qs}}$

Thus:

$\mathrm{i}_{\mathrm{qs}-\mathrm{ref}}=\frac{3}{2 \mathrm{p} \phi_{\mathrm{f}}} \mathrm{T}_{\mathrm{em}-\mathrm{ref}}$

The open loop transfer function is:

$G(s)=\left(k_{p}+\frac{k_{i}}{s}\right)\left(\frac{1}{R_{s}+s L_{d}}\right)=\frac{s+\frac{k_{i}}{k_{p}}}{\frac{s}{k_{p}}} \frac{\frac{1}{R_{s}}}{s+\frac{R_{s}}{L_{d}}}$

We use the method of poles compensation in order to eliminate the zero present on the transfer function $[11,12]$. We pose:

$$
\frac{\mathrm{k}_{\mathrm{i}}}{\mathrm{k}_{\mathrm{p}}}=\frac{\mathrm{R}_{\mathrm{s}}}{\mathrm{L}_{\mathrm{d}}}
$$


Thus:

$\mathrm{G}(\mathrm{s})=\frac{\mathrm{k}_{\mathrm{p}} \frac{1}{\mathrm{~L}_{\mathrm{d}}}}{\mathrm{s}}=\frac{1}{\tau_{\mathrm{r}} \mathrm{s}}$

Where $\tau \mathrm{r}$ is response time:

$\tau_{\mathrm{r}}=\frac{\mathrm{L}_{\mathrm{d}}}{\mathrm{k}_{\mathrm{p}}}$

In closed loop we will have:

$\mathrm{F}(\mathrm{s})=\frac{1}{1+\tau_{\mathrm{r}} \mathrm{s}}$

Therefore, the parameters $\mathrm{kp}$ and ki of PI controller are given by:

$\left\{\begin{array}{l}\mathrm{k}_{\mathrm{p}}=\frac{1}{\tau_{\mathrm{r}}} \mathrm{L}_{\mathrm{d}} \\ \mathrm{k}_{\mathrm{i}}=\frac{1}{\tau_{\mathrm{r}}} \mathrm{R}_{\mathrm{s}}\end{array}\right.$

We chose: $\tau \mathrm{r}=10 \mathrm{~ms}$

\subsection{Control of the grid side converter and DC link voltage}

The open loop transfer function for the grid filter controlled by PI is:

$\mathrm{G}(\mathrm{s})=\left(\mathrm{k}_{\mathrm{p}}+\frac{\mathrm{k}_{\mathrm{i}}}{\mathrm{s}}\right)\left(\frac{1}{\mathrm{R}_{\mathrm{g}}+\mathrm{sL} \mathrm{g}}\right)$

Therefore, the parameters of PI controller are:

$$
\left\{\begin{array}{l}
\mathrm{k}_{\mathrm{p}}=\frac{1}{\tau_{\mathrm{r}}} \mathrm{L}_{\mathrm{g}} \\
\mathrm{k}_{\mathrm{i}}=\frac{1}{\tau_{\mathrm{r}}} \mathrm{R}_{\mathrm{g}}
\end{array}\right.
$$

The deference between the active power generated by the wind generator $\mathrm{P}_{\mathrm{m}}$ and the delivered power to grid $\mathrm{P}_{\mathrm{g}}$ is stored in the DC-link capacitor, the structure of DC link voltage control is shown in Figure 6. The converters losses are neglected, therefore the equation of the dc-link voltage is expressed by:

$$
\mathrm{P}_{\mathrm{DC}}=\mathrm{P}_{\mathrm{m}}-\mathrm{P}_{\mathrm{g}}
$$

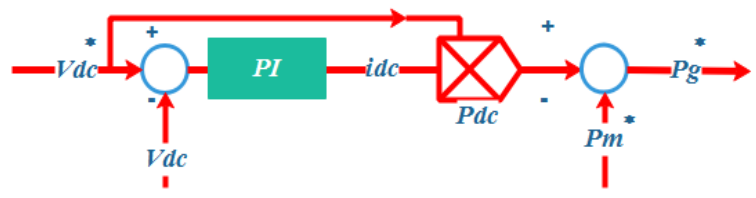

Figure 6. Structure of DC link voltage control

Figure 7 shows the PI control structure applied to the generator and grid side converter. 


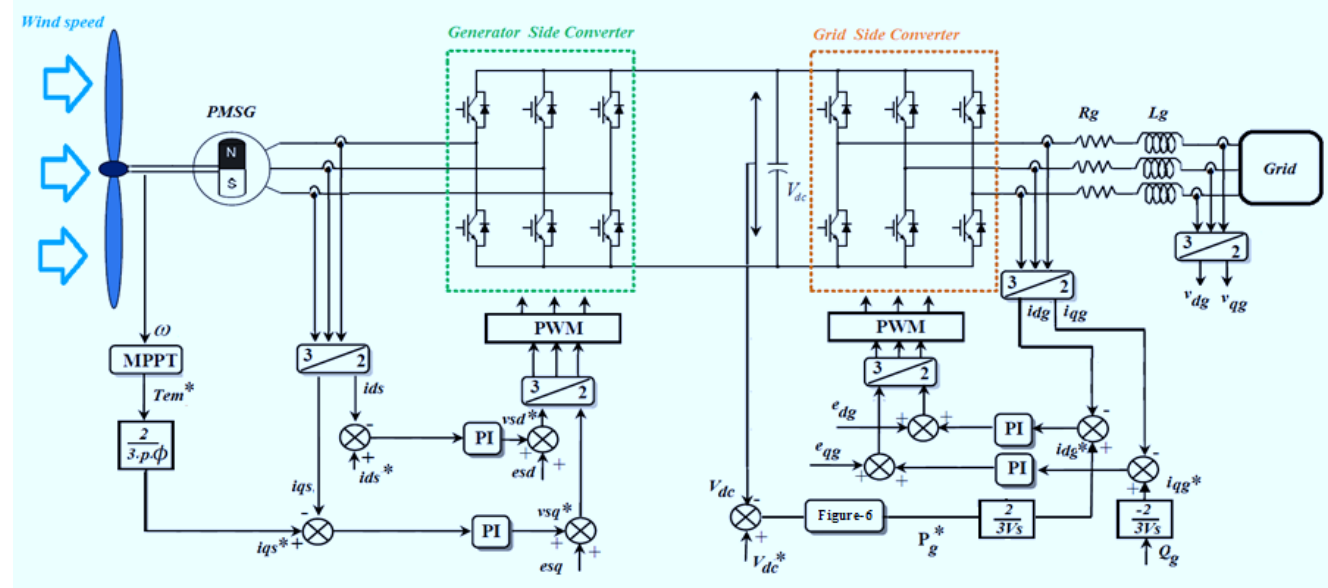

Figure 7. PI Control structure of the wind system based on PMSG

\section{CONTROL OF THE WIND SYSTEM BY ADRC CONTROLLER}

\subsection{Control of the generator side converter}

The currents of the stator are rearranged as follow:

$\left\{\begin{array}{c}\frac{\mathrm{dI}_{s d}}{\mathrm{dt}}=-\frac{\mathrm{R}_{\mathrm{s}}}{\mathrm{L}_{\mathrm{d}}} \mathrm{I}_{s d}+\omega_{\mathrm{s}} \frac{\mathrm{L}_{\mathrm{q}}}{\mathrm{L}_{\mathrm{d}}} \mathrm{I}_{s q}+\frac{1}{\mathrm{~L}_{\mathrm{d}}} \mathrm{V}_{\mathrm{sd}} \\ \frac{\mathrm{dI} \mathrm{sq}_{\mathrm{sq}}}{\mathrm{dt}}=-\frac{\mathrm{R}_{\mathrm{s}}}{\mathrm{L}_{\mathrm{q}}} \mathrm{I}_{\mathrm{sq}}-\omega_{\mathrm{s}} \frac{\mathrm{L}_{\mathrm{d}}}{\mathrm{L}_{\mathrm{q}}} \mathrm{I}_{\mathrm{sd}}-\frac{1}{\mathrm{~L}_{\mathrm{q}}} \phi_{\mathrm{f}}+\frac{1}{\mathrm{~L}_{\mathrm{q}}} \mathrm{V}_{\mathrm{sq}}\end{array}\right.$

These expressions can be written in the following form:

$\frac{d I_{s d}}{d t}=f\left(I_{s d}, d, t\right)+b_{0} u(t)$

Where:

$\left\{\begin{array}{c}f\left(I_{s d}, d, t\right)=-\frac{R_{s}}{L_{d}} I_{s d}+\omega_{s} \frac{L_{q}}{L_{d}} I_{s q} \\ u(t)=V_{s d} \quad \text { and } \quad b_{0}=\frac{1}{L_{d}}\end{array}\right.$

Where:

$\frac{d I_{s q}}{d t}=f\left(I_{s q}, d, t\right)+b_{0} u(t)$

In the same way:

$$
\left\{\begin{array}{c}
f\left(I_{s q}, d, t\right)=-\frac{R_{s}}{L_{q}} I_{s q}-\omega_{s} \frac{L_{d}}{L_{q}} I_{s d}-\frac{1}{L_{q}} \phi_{f} \\
u(t)=V_{s q} \quad \text { and } \quad b_{0}=\frac{1}{L_{q}}
\end{array}\right.
$$

5.2. Control of the grid side converter and DC link voltage 5.2.1. The currents of the grid filter

The currents of the grid filter are rearranged as follow:

$$
\left\{\begin{array}{l}
\frac{\mathrm{dI}_{\mathrm{dg}}}{\mathrm{dt}}=-\frac{1}{\mathrm{Lg}_{\mathrm{g}}} \mathrm{V}_{\mathrm{dg}}-\frac{\mathrm{R}_{\mathrm{g}}}{\mathrm{Lg}_{\mathrm{g}}} \mathrm{I}_{\mathrm{dg}}+\omega_{\mathrm{s}} \frac{\mathrm{L}_{\mathrm{q}}}{\mathrm{L}_{\mathrm{d}}} \mathrm{I}_{\mathrm{qg}}+\frac{1}{\mathrm{Lg}_{\mathrm{g}}} \mathrm{V}_{\mathrm{md}} \\
\frac{\mathrm{dI}_{\mathrm{qg}}}{\mathrm{dt}}=-\frac{1}{\mathrm{~L}_{\mathrm{g}}} \mathrm{I}_{\mathrm{qg}}-\frac{\mathrm{R}_{\mathrm{g}}}{\mathrm{L}_{\mathrm{g}}} \mathrm{I}_{\mathrm{qg}}-\omega_{\mathrm{s}} \frac{\mathrm{L}_{\mathrm{d}}}{\mathrm{L}_{\mathrm{q}}} \mathrm{I}_{\mathrm{dg}}+\frac{1}{\mathrm{~L}_{\mathrm{g}}} \mathrm{V}_{\mathrm{mq}}
\end{array}\right.
$$


These expressions can be written in the following form:

$\frac{d I_{d g}}{d t}=f\left(I_{d g}, d, t\right)+b_{0} u(t)$

Where:

$$
\left\{\begin{array}{c}
f\left(I_{d g}, d, t\right)=-\frac{1}{L_{g}} V_{d g}-\frac{R_{g}}{L_{g}} I_{d g}+\omega_{s} \frac{L_{q}}{L_{d}} I_{q g} \\
u(t)=V_{m d} \quad \text { and } \quad b_{0}=\frac{1}{L_{g}}
\end{array}\right.
$$

Where:

$$
\frac{\mathrm{dI}_{\mathrm{qg}}}{\mathrm{dt}}=\mathrm{f}\left(\mathrm{I}_{\mathrm{qg}}, \mathrm{d}, \mathrm{t}\right)+\mathrm{b}_{0} \mathrm{u}(\mathrm{t})
$$

In the same way:

$$
\left\{\begin{array}{c}
f\left(I_{q g}, d, t\right)=-\frac{1}{L_{g}} I_{q g}-\frac{R_{g}}{L_{g}} I_{q g}-\omega_{s} \frac{L_{d}}{L_{q}} I_{d g} \\
u(t)=V_{m q} \quad \text { and } \quad b_{0}=\frac{1}{L_{g}}
\end{array}\right.
$$

\subsubsection{DC bus voltage control}

The power on the DC link Capacitor can be given by:

$$
\mathrm{P}_{\mathrm{dc}}=C \mathrm{~V}_{\mathrm{dc}} \frac{\mathrm{dV_{ \textrm {dc } }}}{\mathrm{dt}}=\mathrm{V}_{\mathrm{dc}}\left(\mathrm{i}_{1}-\mathrm{i}_{2}\right)
$$

When the losses in the RL filter, the capacitor and in the two power converters are neglected, the powers across the DC bus is the difference between the generator power Pm and grid power Pg:

$$
\mathrm{P}_{\mathrm{dc}}=\mathrm{P}_{\mathrm{m}}-\mathrm{P}_{\mathrm{g}}
$$

Or:

$$
\begin{aligned}
& C V_{d c} \frac{d V_{d c}}{d t}=V_{d c} i_{1}-\frac{3}{2} V_{d g} i_{d g} \\
& \frac{d V_{d c}{ }^{2}}{d t}=\frac{2 V_{d c}}{C} i_{1}-\frac{3 V_{d g}}{C} i_{d g}
\end{aligned}
$$

Taking $\mathrm{A}=\mathrm{Vdc}^{2}$ :

$$
\frac{\mathrm{dA}}{\mathrm{dt}}=\frac{2 \sqrt{\mathrm{A}}}{\mathrm{C}} \mathrm{i}_{1}-\frac{3 \mathrm{~V}_{\mathrm{dg}}}{\mathrm{C}} \mathrm{i}_{\mathrm{dg}}
$$

Thus:

$$
\left\{\begin{array}{r}
f(A, d, t)=\frac{2 \sqrt{A}}{C} i_{1} \\
u(t)=i_{d g} \quad \text { and } \quad b_{0}=-\frac{3 V_{d g}}{C}
\end{array}\right.
$$

Figure 8 shows the ADRC control structure applied to the generator and grid side converter. 


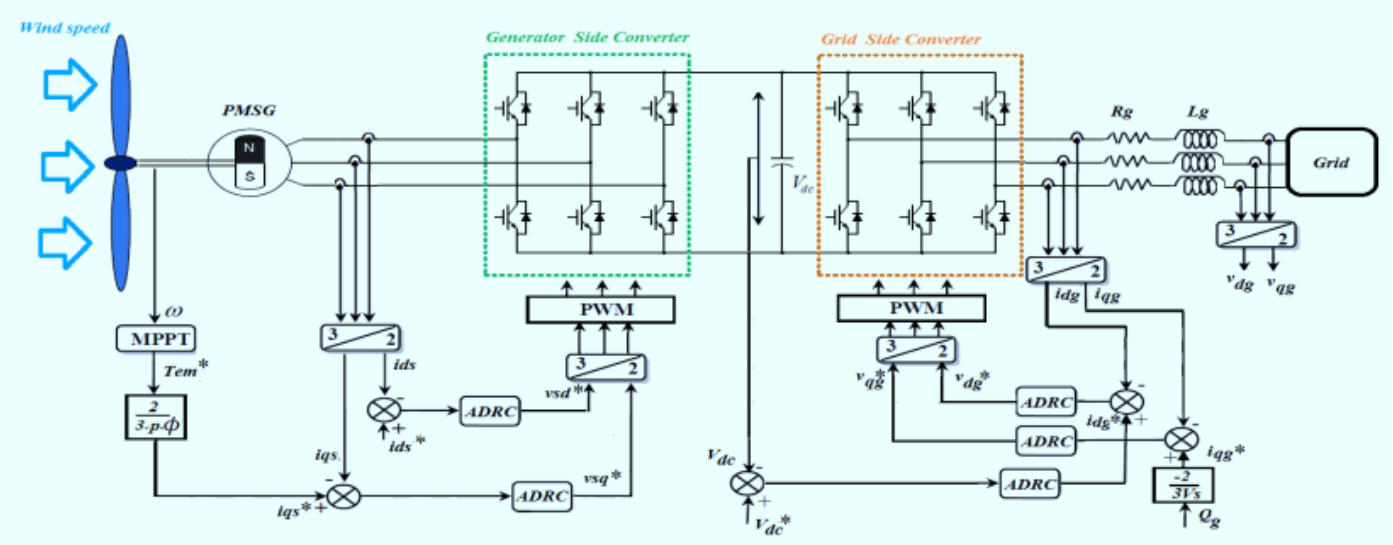

Figure 8. ADRC Control structure of the wind system based on PMSG

\section{SIMULATION RESULTS AND DISCUSSION}

As shown in Figure 9, the simulation was carried out with MATLAB/SIMULINK in order to validate the control strategy studied in this work. The system consists of several blocks, for example the turbine model with its wind profil, the model inverters with its parameters, and controllers based on the ADRC in Figure 10 and PI approach. All parameters are given in Appendix. A random wind profile is shown in Figure 11. To extract the maximum wind energy of the wind speed, an MPPT strategy is adopted. In order to maintain the DC-link voltage constant, a control of the grid side converter is necessary. This technique is based on the control of direct and quadratic grid currents, and ensures also an exchange of active and reactive powers between the stator of the PMSG and the grid. To attain the unity power factor, it's necessary to regulate the grid reactive power to its desired value. In Figure 12, the rotor speed track the profil of the wind which allows the efficiency of the MPPT strategy.

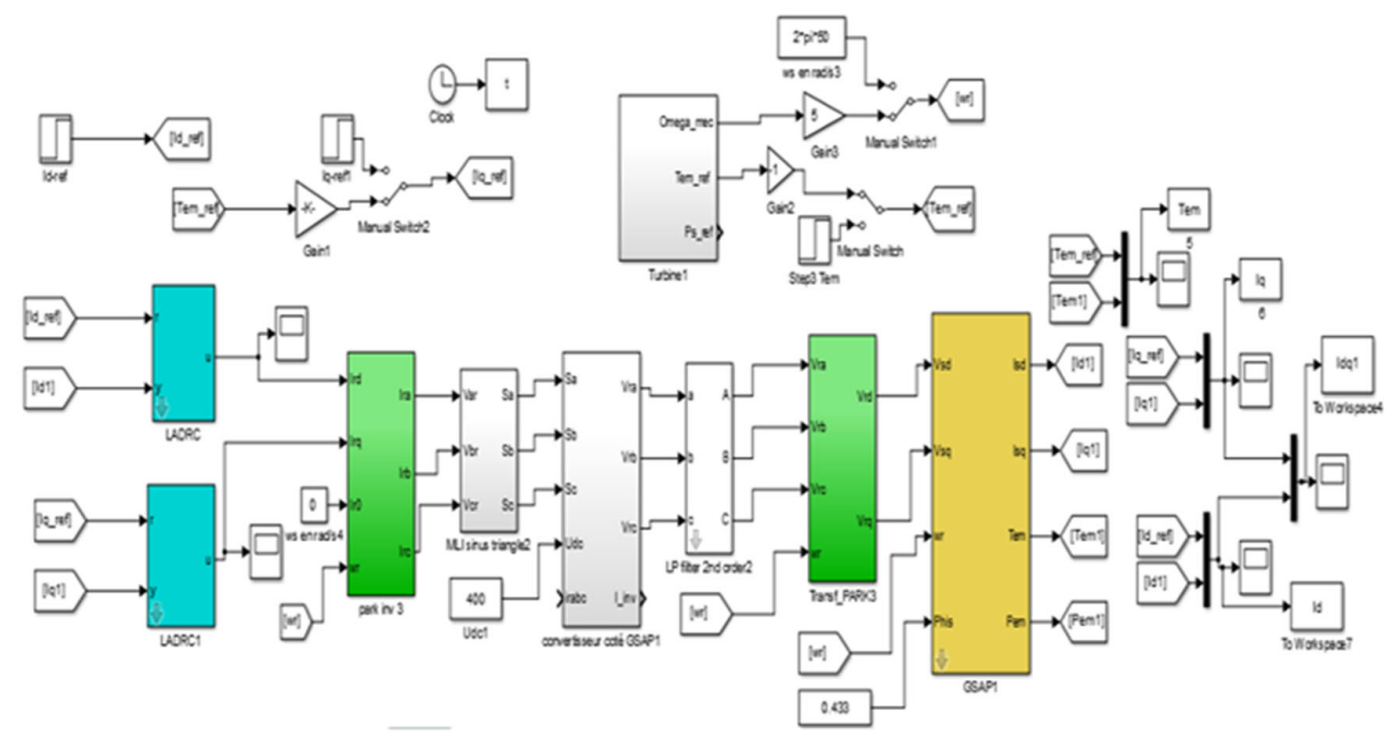

Figure 9. The whole system simulation 


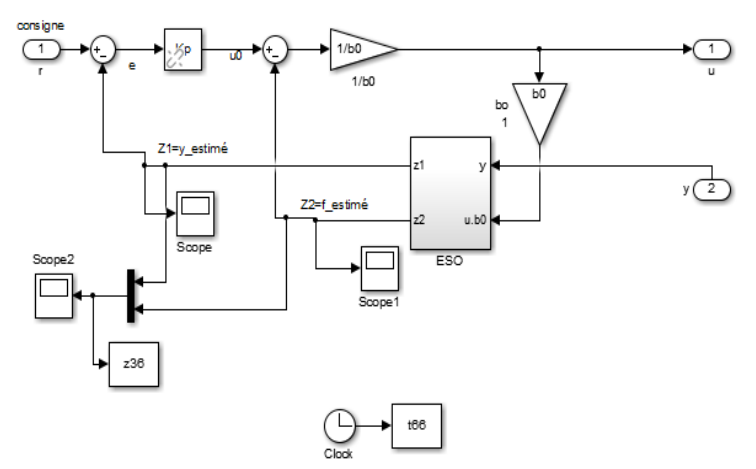

Figure 10. ADRC block conception

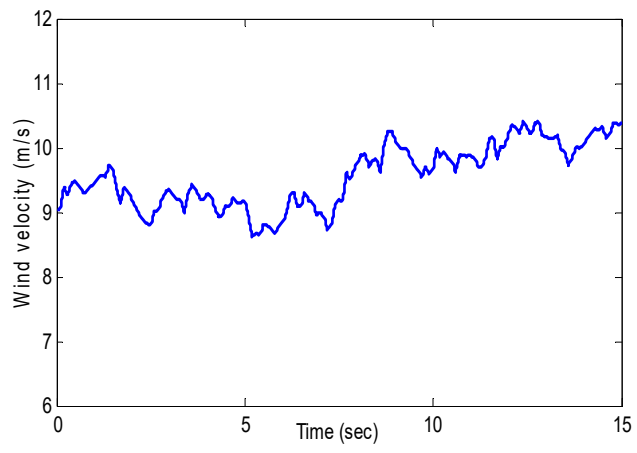

Figure 11. Profile of Wind speed

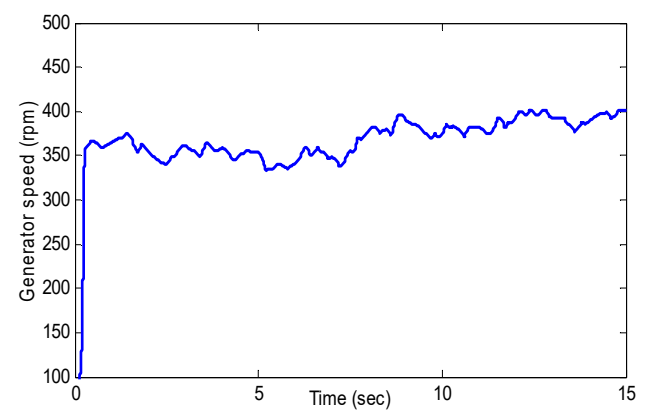

Figure 12. Rotor Speed of PMSG

\subsection{Test of reference tracking}

In Figure 15, the reference direct current $\mathrm{I}_{\mathrm{sd}-\mathrm{ref}}$ is fixed at zero in order to get the unity power factor for the generator side converter (GSC). Figures 13 to 17 illustrate respectively the electromagnetic torque, the stator current, reactive power of grid and DC link voltage variations obtained by using the PI control and the linear ADRC controller. These parameters converge and tracks perfectly as their references (Tem-ref, Isd-ref, Isq-ref, Qg-ref and Vdc-ref), but with a remarkable static error and an important response time for the PI controllers. We can also notice that the response of these parameters is slow and presents some overshoots shown clearly in zoom figures. The main importance factor to analyze the performance of the ADRC controllers, according to fast variation of the references is described in Table 1. It shows a very good performance for the tracking test with high accuracy against to wind speed variation, fast dynamic response, a good stability comparing to PI methods, simplicity of design and implementation.

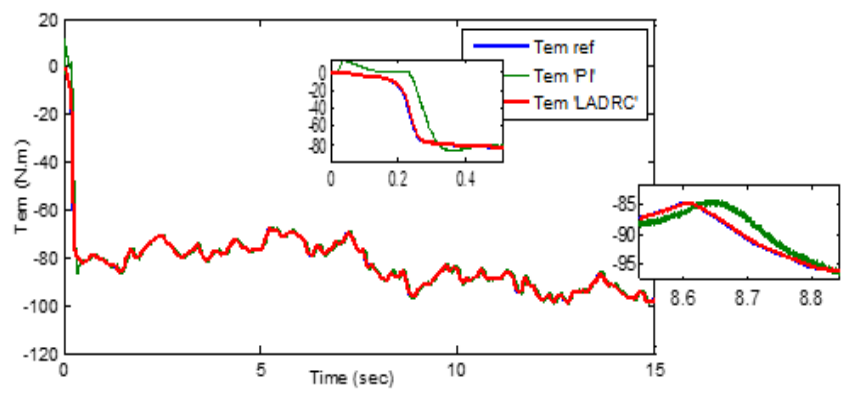

Figure 13. Electromagnetic torque of PMSG 


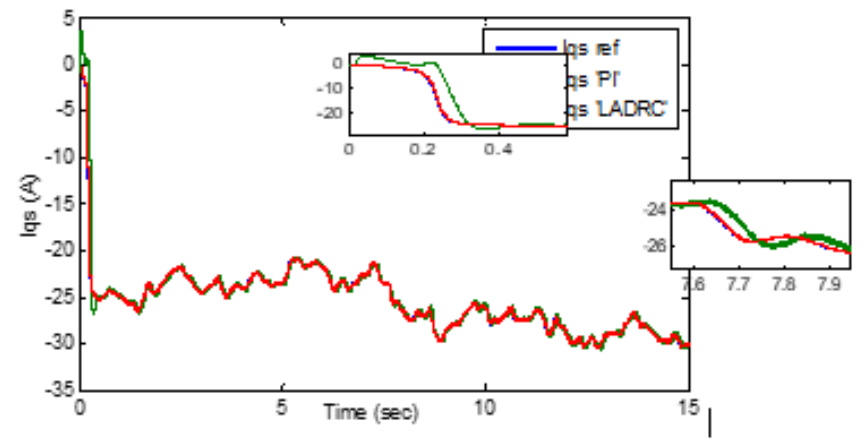

Figure 14. q-axis stator current

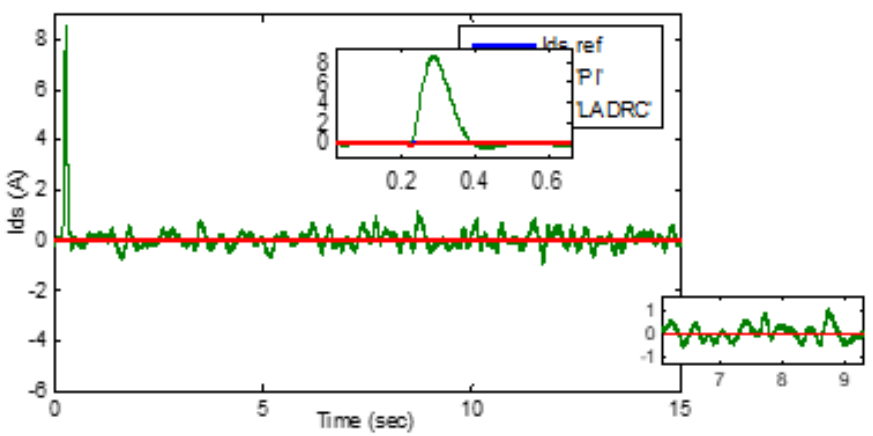

Figure 15. d-axis stator current

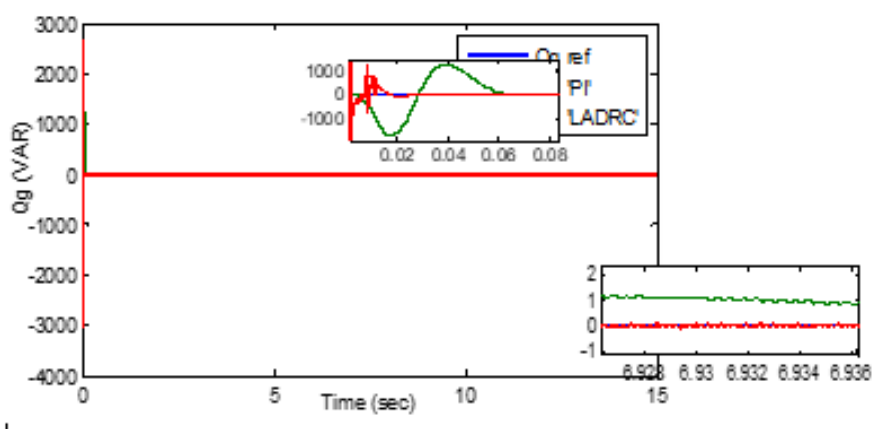

Figure 16. Reactive power of grid

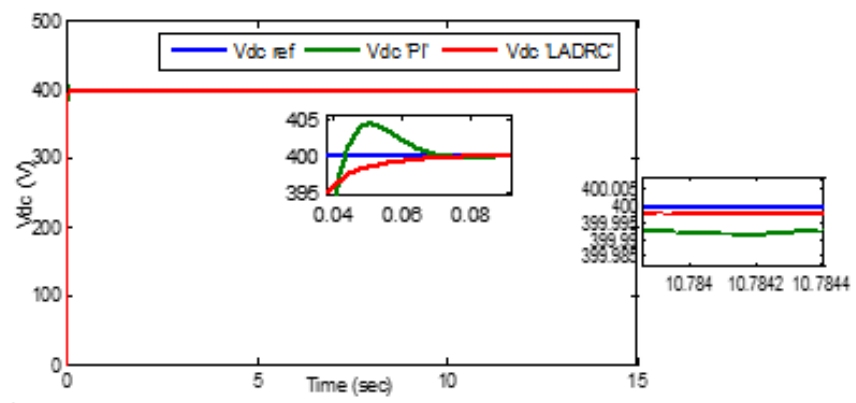

Figure.17 Vdc link voltage 
Table 1. The system responses Parameters

\begin{tabular}{lll}
\hline Type ofController & PI & ADRC \\
\hline Rise Time (s) & 0.1 & 0.06 \\
Settling time(s) & 0.15 & 0.07 \\
Overshoot (\%) & 1 & 0 \\
Steady state error (\%) & 5 & 0.02 \\
\hline
\end{tabular}

\subsection{Test of robustness}

In order to investigate the robustness of the proposed ADRC control algorithm, two cases were selected in which we have changed the internal parameter of the PMSG. In the first one, an increase of the $30 \%$ of the stator resistance nominal value is applied. Figure 18 and 19 shows results of a comparison between ADRC and PI controllers. It can be noticed that the characteristics have been regulated to its reference value. ADRC controllers present excellent performances with good efficiency, smaller overshoot in the reactive power of grid and DC bus voltage, fast response and neglected oscillation in the regulation of the direct stator current to zero.

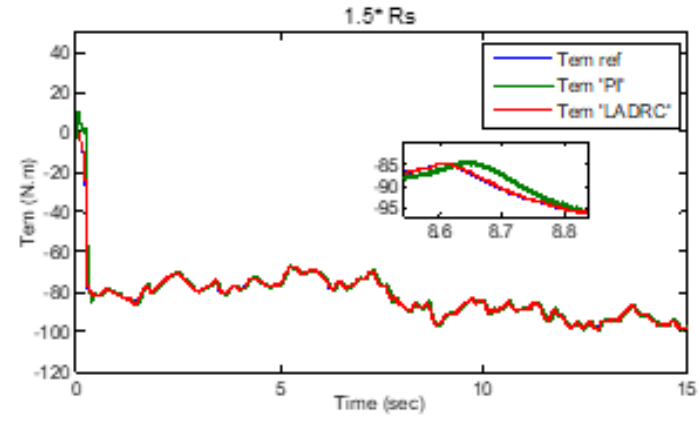

Figure 18. Electromagnetic torque of PMSG

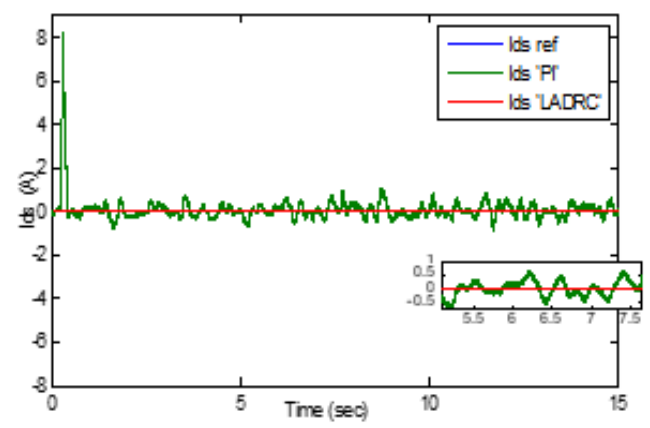

Figure 19. d-axis stator current

In the second case, an increase of the stator inductance nominal value with $20 \%$ is applied. Figures 20 and 21 illustrate respectively, the electromagnetic torque, the direct stator current. It is noted that the whole characteristics is regulated to its set value, and this results obtained by ADRC controllers are clearly more efficient than the classical PI.

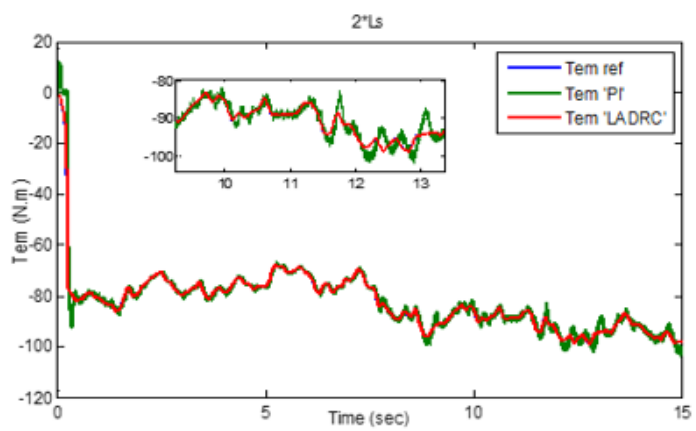

Figure 20. Electromagnetic torque of PMSG

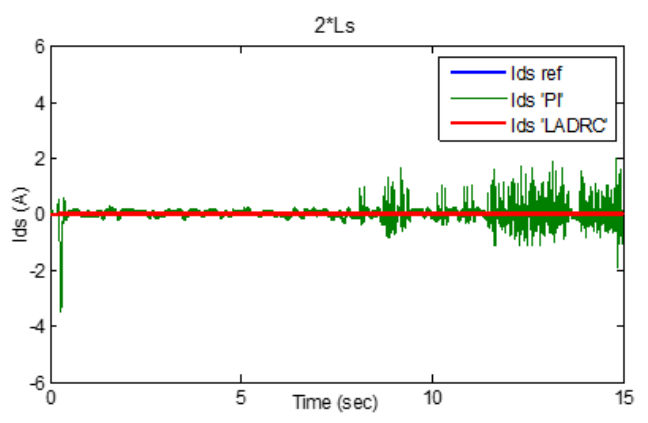

Figure 21. d-axis stator current

\subsection{Operation with grid faults (grid voltage dip)}

A symmetrical grid voltage dip is applied to evaluate the performances of our wind energy system controlled by ADRC strategy. Figure 22 shows that the voltage sag occurs at $t=5 \mathrm{~s}$. DC bus voltage is controlled by ADRC and PI algorithm. As shown in Figure 23, the amplitude voltage oscillations is very 
remarkable and present more than $1 \%$ comparing with the rated voltage in ADRC methods. If the voltage sag was very dip, a PI controller presents more oscillations which converge to unstable system.

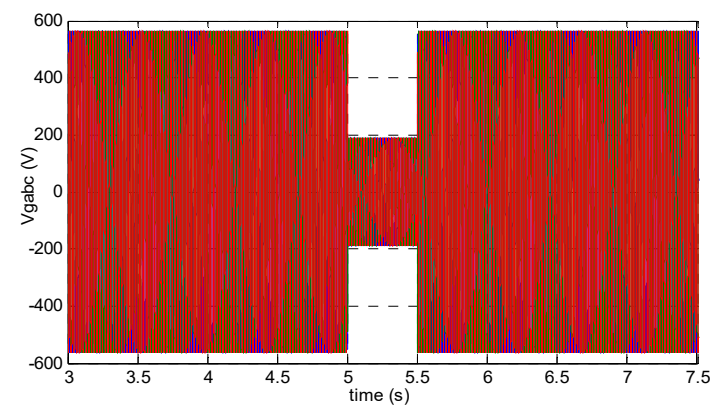

Figure.22 Grid voltage

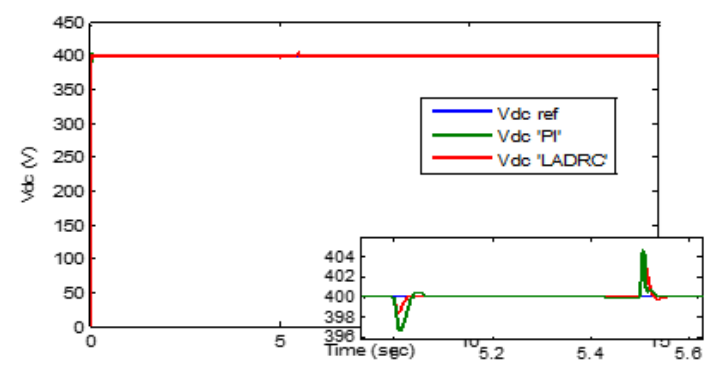

Figure. $23 \mathrm{~V}_{\mathrm{dc}}$ link voltage

\section{CONCLUSION}

In this work, a wind turbine conversion system using a PMSG connected to the grid were studied under two cases: normal and grid faults (voltage dip).To evaluate the performances of our system, a conventional PI and the active disturbance rejection control (ADRC) were compared. Simulations under Matlab/Simulink environment shows that the proposed ADRC methods gives very satisfactory characteristics with good efficiency, fast tracking and robustness for internal parametric variations of the PMSG, and external disturbances compared to the conventional PI controller even with the voltage dips effect.

\section{APPENDIX}

Table 2. PMSG Parameters [8]

\begin{tabular}{cc}
\hline Rated power & $6 \mathrm{~kW}$ \\
\hline Pole pairsnumber $\mathrm{p}$ & 5 \\
Stator resistance $\mathrm{R}_{\mathrm{s}}$ & $0.425 \Omega$ \\
Inductance $\mathrm{L}_{\mathrm{d}}$ & $0.0084 \mathrm{H}$ \\
Inductance $\mathrm{L}_{\mathrm{q}}$ & $0.0084 \mathrm{H}$ \\
Rotor Flux $\phi_{\mathrm{f}}$ & $0.433 \mathrm{wb}$ \\
Moment of inertia J 0.41 kg.m2 & $0.01197 \mathrm{~kg} . \mathrm{m}^{2}$ \\
DC link voltage $\mathrm{U}_{\mathrm{dc}}$ & $400 \mathrm{~V}$ \\
\hline
\end{tabular}

Table-4. Grid and DC link Parameters [8]

\begin{tabular}{|c|c|c|}
\hline dc-link voltage & & $400 \mathrm{~V}$ \\
\hline Capacitor of the dc-link & $0.41 \mathrm{~kg} . \mathrm{m} 2$ & $10 \mathrm{mF}$ \\
\hline Grid frequency & & $50 \mathrm{~Hz}$ \\
\hline Grid inductance & & $1 \mathrm{mH}$ \\
\hline Grid resistance & & $0.01 \Omega$ \\
\hline
\end{tabular}

Table 3. Turbine Parameters [8]

\begin{tabular}{cc}
\hline Density of Air & $1.225 \mathrm{~kg} . \mathrm{m} 3$ \\
\hline Total moment of inertia Jt $0.41 \mathrm{~kg} . \mathrm{m} 2$ & $0.02 \mathrm{~kg} . \mathrm{m} 2$ \\
Optimal tip speed ratio $\lambda$ opt & 8.1 \\
Maximal power coefficient CPmax & 0.48 \\
Turbine diameter D & $2 \mathrm{~m}$ \\
\hline
\end{tabular}

Table 5. ADRC Controller Parameters

\begin{tabular}{cc}
\hline Parameter gain $\mathrm{b}_{0}=1 / \mathrm{L}_{\mathrm{s}}$ & 119.0476 \\
\hline controller gain $\mathrm{K}_{\mathrm{p}}=-\mathrm{S}_{\mathrm{CL}}$ & 400 \\
pole of ESO $\mathrm{S}_{\mathrm{ESO}}=3 \mathrm{~S}_{\mathrm{CL}}$ & -1200 \\
Extended state observer gains (ESO) & $\beta 1=2400$ \\
& $\beta_{2}=1440000$ \\
\hline
\end{tabular}

Table 6. PI Controller Parameters

Int J Pow Elec \& Dri Syst, Vol. 11, No. 2, June 2020 : 953 - 968 


\begin{tabular}{cc}
\hline Parameter gain $\mathrm{b}_{0}=1 / \mathrm{L}_{\mathrm{s}}$ & 119.0476 \\
\hline controller gain $\mathrm{K}_{\mathrm{p}}=-\mathrm{S}_{\mathrm{CL}}$ & 400 \\
pole of ESO $\mathrm{S}_{\mathrm{ESO}}=3 \mathrm{~S}_{\mathrm{CL}}$ & -1200 \\
Extended state observer gains (ESO) & $\beta 1=2400$ \\
& $\beta_{2}=1440000$ \\
\hline
\end{tabular}

\section{REFERENCES}

[1] N. K. Jena, H. Pradhan, A. Choudhury, K. B. Mohanty, andS. K. Sanyal, "A Novel SMC Based Vector Control Strategy Usedfor Decoupled Control of PMSG based VariableSpeed Wind Turbine System". International Conference on Circuit, Power and Computing Technologies (ICCPCT), IEEE, pp.1-6, 2017.

[2] M. Cao, S. Li, J. Li, Y. Wu, H. Sun, “A Model-Compensation ADRC Strategy of Wind Energy Conversion System with Direct-Driven PMSG". International Conference on 37th Chinese Control Conference (CCC), IEEE, pp. 7520-7525, 2018.

[3] R. I. Putri, M. Rifa'I, L. Jasa, A. Priyadi, P. Margo, and H.P. Mauridhi, "Modeling and Control of Permanent Magnet Synchronous Generator Variable Speed Wind turbine", International Conference on Smart Green Technology in Electrical and Information Systems (ICSGTEIS), IEEE, pp.16-20, 2016.

[4] D.Hammoumi, C. El Bekkali, M. Karim, M. Taoussi, B. Bossoufi, A. Lagrioui, "Control wind energy system to variable speed based on the permanent magnet synchronous generator", International Conference on Advanced Technologies for Signal and Image Processing (ATSIP) May 22-24, Fez, Morroco.IEEE, pp.1-6, 2017.

[5] Y. Boussairi, A. Abouloifa, A. Hamdoun, C. Aouadi, I. Lachkar, and F. Giri, "Nonlinear Control of Permanent Magnet Synchronous Generator Grid-Connected Applied to Wind Energy Conversion System", International Conference on Industrial Technology (ICIT), IEEE, pp.452-457, 2017.

[6] J. Han, "From PID to Active Disturbance Rejection Control", IEEE trans. on Industrial Electronics, 56, pp.900906, 2009.

[7] D. Satyajit, S. Bidyadhar, "A Two Degree of Freedom Internal Model based Active Disturbance Rejection Controller for a Wind Energy Conversion System", International Journal of Emerging and Selected Topics in Power Electronics, IEEE, pp.1-8, 2019.

[8] R. Chakib, A. Essadki, and M. Cherkaoui, "Active Disturbance Rejection Control for Wind System Based on a DFIG", World Academy of Science, Engineering and Technology, International Journal of Electrical, Computer, Energetic, Electronic and Communication Engineering, vol. 8, No. 8, pp.1313-1322, 2014.

[9] O. Elbeji, M. Ben Hamed, and L. Sbita, "PMSG Wind Energy Conversion System: Modeling and Control". International Journal of Modern Nonlinear Theory and Application, vol. 3, pp.88-97, 2014.

[10] S. Vijayalakshmi, M. Padmanabhan, C.S. Santhosh and R. Muthukumar, "Standalone Wind Turbine using DC Grid for LED Street Light Application”, International Journal of Engineering Research \& Technology (IJERT), vol. 6 , No. 7, pp.1-6, 2018

[11] K. Patil, and B. Mehta, "Modeling and Control of Variable Speed Wind Turbine with Permanent Magnet Synchronous Generator", International Conference on Advances in Green Energy (ICAGE), pp.258-264, 2014.

[12] M. A. Husain, and A. Tariq, "Modeling and Study of a Standalone PMSG Wind Generation System Using MATLAB/SIMULINK", Universal Journal of Electrical and Electronic Engineering, vol. 2, No. 7, pp.270-277, 2014

[13] S. Belakehal, A. Bentounsi, M. Merzoug, and H. Benalla, "Modélisation et commande d'une génératrice Synchrone à aimants permanents dédiée à la conversion de l'énergie éolienne". Revue des Energies Renouvelables, vol. 13, No. 1, pp.149-161, 2010.

[14] Y. S. Kim, I. Y. Chung, S. I. and Moon, "Tuning of the PI Controller Parameters of a PMSG Wind Turbine to Improve Control Performance under Various Wind Speeds", Energies journal, vol. 8, No. 2, pp.1-6, 2015.

[15] E. Mahersi, and A. Kheder, "Adaptive Backstepping Control Applied to Wind PMSG System". International Renewable Energy Congress (IREC), IEEE, pp. 1-6.

[16] G. Herbst, "A Simulative Study on Active Disturbance Rejection Control (ADRC) as a Control Tool for Practitioners", Electronics, pp. 246-279, 2013.

[17] C. Z. El Archi, T. Nasser, and A. Essadki, "Power Control of DFIG Based Wind System: Comparison Between Active Disturbance Rejection Controller and PI Controller". ARPN Journal of Engineering and Applied Sciences, vol. 11, No. 23, pp.13980-13989, 2016.

[18] S. Wang, W. Tan, and D. Li, "Design of Linear ADRC for Load Frequency Control of Power Systems with Wind Turbine", 14th IEEE International Conference on Control, Automation, Robotics and Vision (ICARCV), Dallas, TX, USA, pp.1-5, 2016.

[19] R. Mittal, K. S. Sandhu, and D. K. Jain, "Low Voltage Ride-Through (LVRT) Of Grid Interfaced Wind Driven PMSG", ARPN Journal of Engineering and Applied Sciences, vol. 4, No. 5, pp.73-77, 2009.

[20] E. Mahersi, A. Khedher, and M. Faouzi, "The Wind energy Conversion System Using PMSG Controlled by Vector Control and SMC Strategies", International Journal of Renewable Energy Research, vol. 3, No. 1, pp.41-50, 2013.

[21] R. I. Putri, M. Rifa'I, M. Pujiantara, A. Priyadil, and M.H. Purnomo, "Fuzzy MPPT Controller for Small Scale Stand Alone PMSG Wind Turbine", ARPN Journal of Engineering and Applied Sciences, vol. 12, No. 1, pp.270$277,2017$. 


\section{BIOGRAPHIES OF AUTHORS}

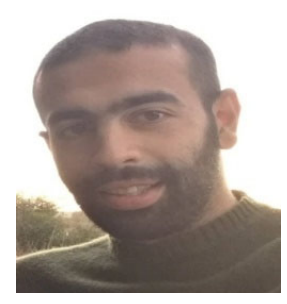

BARRADI Youssef was born in Kenitra, Morocco. He is $\mathrm{PhD}$ student in electrical engineering from University Mohammed V. His research interests include Solar and Wind Energy Conversion System, neural network and robust backstepping and ADRC for control and simulation.

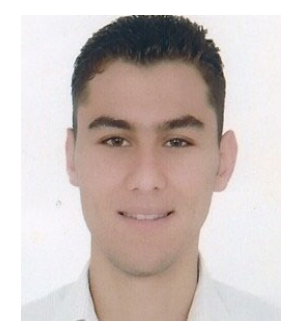

KHALDI Naoufel was born in Rabat, Morocco. He received his $\mathrm{PhD}$ degree in electrical engineering from University Mohammed V in 2019. His research interests include solar energy conversion, neural network and robust backstepping for control, simulation and supervision in real time. Presently, he is a professor at Moroccan Science school of engineering Casa since 2015.

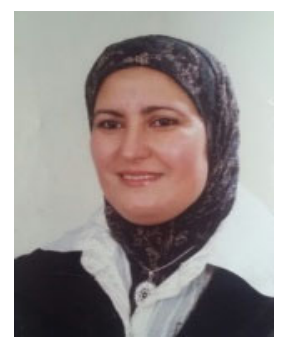

ZAZI Khalida received the degree of engineer in electromechanical in 1988 fromRabat Higher School of Mines (ESMR), and preparatory certificate of research in 1997from School Mohammedia of Engineering and a doctoral thesis in photovoltaics in 2017 fromFaculty of Science and Technology Mohanmmadia, University Hassan II Casablanca. Havingworked as a researcher at the National Center for Scientific and Technical Research of Rabat (CNRST) in different laboratories: laboratory of scientific instrumentation and the laboratoryof geophysics and in the unit of technologies and economy of renewable energies. Currentlyshe is a teacher at the higher normal school of Technical Education of Rabat (ENSET)University Mohammed V Rabat since 2014.

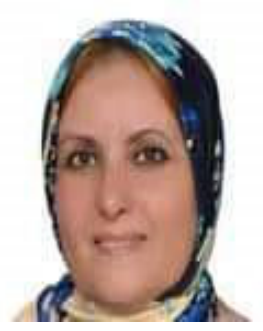

ZAZI Malika received the degree of engineer in automatics and industrial informatics in 1984 from School Mohammedia of Engineering, and the Ph.D. degree in electrical engineering in 2006 from Mohammadia School of engineering, University Mohammedia V Rabat. She has specialized in the linear and nonlinear control systems. Presently, she is serving as is director of pedagogical affairs and head of Electro Technical Robotic and Automatic Research Team ERERA. She has over 30years of teaching experience. She is guiding some doctorate students in Renewable Energy, Diagnostic, Robust Control and Electrical Engineering. 